STUDIA PRAWNO-EKONOMICZNE, T. CXIX, 2021

PL ISSN 0081-6841; e-ISSN 2450-8179 $\quad$ s. 297-314

https://doi.org/10.26485/SPE/2021/119/16

\title{
Bartłomiej PILCH*
}

iD https://orcid.org/0000-0002-0081-4050

\section{WPLYW WYBRANYCH ZMIENNYCH MAKROEKONOMICZNYCH NA LICZBE PIERWSZYCH OFERT PUBLICZNYCH - SYTUACJA POLSKIEGO RYNKU GIELDOWEGO}

\begin{abstract}
Abstrakt
Przedmiot badań: Analizie poddano wpływ zmiennych makroekonomicznych na liczbę pierwszych ofert publicznych (IPO). Poszczególne wskaźniki ogólnogospodarcze oddziałują na rynek giełdowy w różny sposób. Zróżnicowane są także wyniki badań biorących pod uwagę ich wpływ na liczbę debiutów giełdowych przeprowadzanych w różnych krajach. Wobec tego zdecydowano się przeprowadzić analizę w tym zakresie, skupiając się na Giełdzie Papierów Wartościowych w Warszawie (GPW), pośrednio starając się sprawdzić, czy wyniki badań zagranicznych znajdują odzwierciedlenie w sytuacji polskiego rynku.

Cel badawczy: Głównym motywem podjęcia badań była weryfikacja wpływu wybranych wskaźników makroekonomicznych na liczbę IPO. Celowi temu podporządkowano następujące hipotezy badawcze: stopa wzrostu PKB pozytywnie wpływa na liczbę debiutów giełdowych, stopa procentowa negatywnie oddziałuje na tę zmienną, wzrost stóp zwrotu z Warszawskiego Indeksu Giełdowego (WIG) przyczynia się do wzrostu liczby IPO.

Metoda badawcza: Empiryczna weryfikacja wpływu zmiennych makroekonomicznych na liczbę IPO przeprowadzona została z użyciem modeli regresji liniowej. Dla modeli rocznych estymacja przebiegała Metodą Najmniejszych Kwadratów (MNK), zaś w przypadku kwartalnych - także Uogólnioną Metodą Najmniejszych Kwadratów (UMNK), w celu uniknięcia heteroskedastyczności reszt. Analizie poddano liczbę IPO w latach 2005-2019, objaśniając ją wskaźnikami (stopą wzrostu PKB, stopą referencyjną NBP, stopą rentowności 10-letnich obligacji skarbowych stopą zwrotu z WIG) opóźnionymi o 1 okres.

Wyniki: Stopa zwrotu z WIG istotnie, pozytywnie oddziaływała na liczbę debiutów giełdowych w kolejnym okresie zarówno w ramach modeli rocznych, jak i kwartalnych. W przypadku pozostałych zmiennych ich istotny wpływ na liczbę IPO zaobserwowano jedynie w przypadku modeli kwartalnych. Stopa wzrostu PKB wykazywała dodatnie powiązanie z liczbą debiutów giełdowych, co zgadza się z postawioną wcześniej hipotezą, podobnie jak w przypadku stóp zwrotu z WIG. Pozytywne oddziaływanie na liczbę IPO zanotowano też w przypadku referencyjnej stopy procentowej - wynik ten różnił się natomiast od oczekiwanego. Abstrahując od rezultatu badania, można wskazać też na celowość wykorzystywania modeli przygotowanych

* Student, Uniwersytet Ekonomicznyw Krakowie; e-mail: bpilch98@gmail.com


nie tylko w oparciu dane roczne, ale także i kwartalne, w przypadku badania wpływu zmiennych makroekonomicznych na liczbę IPO.

Słowa kluczowe: IPO, stopa wzrostu PKB, stopa procentowa, stopa zwrotu z indeksu giełdowego, GPW.

Klasyfikacja JEL: E30, G00

\section{Wstęp}

Zmienne makroekonomiczne niewątpliwie oddziałują na ogólną kondycję gospodarki, w tym na sytuację sektora finansowego, w ramach którego wyróżnić można rynek giełdowy. Wartości wskaźników gospodarczych kluczowych w kontekście rozwoju danego kraju wpływają zarówno na przeciętne stopy zwrotu z walorów notowanych publicznie, jak i na liczbę debiutów giełdowych. Często spotkać można pogląd, wedle którego okresy dobrej koniunktury gospodarczej wiążą się ze zwiększoną liczbą spółek przeprowadzających pierwsze oferty publiczne (w dalszej części niniejszego opracowania pojęcie pierwszej oferty publicznej, IPO - initial public offering, utożsamia się z debiutem giełdowym $)^{1}$. Pojęcie to, które rozumiane jest jako oferta skierowana do 150 lub więcej osób lub do nieoznaczonego adresata, wiąże się z potencjalnymi korzyściami, ale też pewnymi kosztami ${ }^{2}$. Zazwyczaj pierwsza oferta publiczna ukierunkowana jest na pozyskanie funduszy na rozwój działalności danej spółki, aczkolwiek ważną kwestią jest także poprawa wizerunku podmiotu debiutującego na rynku giełdowym. $Z$ drugiej strony, $\mathrm{z}$ wejściem na giełdę wiążą się również pewne wady z punktu widzenia zarządu firmy - konieczność spełniania wymogów informacyjnych czy podawania wybranych danych do publicznej informacji ${ }^{3}$.

Ogółem wyróżnić można wiele motywów podjęcia decyzji o wprowadzeniu papierów wartościowych jednostki do zorganizowanego obrotu giełdowego. Należą do nich czynniki związane z szeroko pojętym otoczeniem spółki, przykładowo makroekonomiczne czy behawioralne, a także determinanty

1 Np. T. Dudycz, Działalność inwestycyjna spółek debiutujacych na Giełdzie Papierów Wartościowych w Warszawie, Oficyna Wydawnicza Politechniki Wrocławskiej, Wrocław 2013, s. 13; R. Ameer, Macroeconomic Factors and IPOs in Malaysia, Asian Academy of Management Journal of Accounting and Finance 2012/8 (1), s. 40; I. Aidrous, S. Glavina, Impact of the Macroeconomic Factors on the Initial Public Offerings in the Gulf Cooperation Countries, Advances in Economics, Business and Management Research 2020/128, s. 2316.

2 S. Okoń, K. Gemra, Zmiany regulacyjne a rynek pierwszych ofert publicznych (IPO) $w$ Polsce, Kwartalnik Nauk o Przedsiębiorstwie 2020/54 (1), s. 82.

3 T. Dudycz, Działalność inwestycyjna spótek debiutujących na Giełdzie..., s. 17-18. 
odnoszące się do działalności danego podmiotu, określające szanse i zagrożenia w kontekście rozwoju jednostki. Do makroekonomicznych czynników zalicza się między innymi Produkt Krajowy Brutto (PKB), stopy procentowe czy stopę zwrotu z indeksu giełdowego ${ }^{4}$. Motyw przeprowadzenia analizy w dalszej części opracowania związany jest właśnie z tego typu zmiennymi - celem niniejszej pracy jest weryfikacja wpływu wybranych wskaźników makroekonomicznych na liczbę IPO, bazując na pierwszych ofertach publicznych przeprowadzanych na Giełdzie Papierów Wartościowych w Warszawie (GPW). Badanie takie powinno pozwolić na określenie, czy w okresach zwiększonego wzrostu PKB, niższych stóp procentowych czy wyższych stóp zwrotu z rynku giełdowego spodziewać się można większej liczby debiutów giełdowych, w które chętnie inwestują inwestorzy zarówno instytucjonalni, jak i prywatni ${ }^{5}$. Ponadto, czy zależności zaobserwowane przez innych badaczy znajdują empiryczne potwierdzenie na przykładzie polskiego rynku, szczególnie przez pryzmat zróżnicowania wyników ich badań. Wnioski płynące z takiej analizy mogą być cennym źródłem informacji dla podmiotów planujących zainwestować kapitał w IPO przeprowadzane na GPW, a także dla samych spółek.

W ramach pierwszej części artykułu wskazano na potencjalne kierunki oddziaływania wybranych wskaźników makroekonomicznych na liczbę IPO, odwołując się do przykładów badań empirycznych. W drugim fragmencie zarysowano metodykę badania. Ostatnia część obejmuje natomiast empiryczną analizę wpływu przedstawionych wcześniej zmiennych na liczbę debiutów giełdowych na przykładzie GPW.

\section{Zmienne makroekonomiczne a liczba IPO - przegląd literatury}

W literaturze przedmiotu wyróżnić można wiele prac skupiających się na wpływie zmiennych makroekonomicznych na określone wartości, związane z rynkiem obrotu papierami wartościowymi - głównie ceny akcji czy indeksy giełdowe ${ }^{6}$. Zazwyczaj ich konkluzja jest jasna-wskaźniki makroekonomiczne

4 E. Ostrowska, M. Deryło, Determinanty rozwoju rynku emisji pierwotnych akcji na Gietdzie Papierów Wartościowych w Warszawie, Zeszyty Naukowe Uniwersytetu Ekonomicznego w Krakowie 2015/937 (1), s. 103.

5 Przykładowo, redukcja zapisów wśród inwestorów indywidualnych na IPO spółek Allegro i PCF Group, debiutujących w IV kwartale 2020 r., wyniosła odpowiednio ok. 85 i 98\%.

6 Np. H. Wiśniewski, Wpływ zmiennych makroekonomicznych na indeksy giełdowe, praca doktorska, Uniwersytet Warszawski, Warszawa 2014; M. Celej, Wpływ czynników makroekonomicznych na ceny akcji na polskim rynku giełdowym, Studia Ekonomiczne. Zeszyty Nau- 
oddziałują na zmienne giełdowe. Występują jednak różnice w natężeniu ich wpływu zauważalne w przypadku krajów o różnym stopniu rozwoju - przykładowo, w objaśnianiu zmian indeksów giełdowych większą skuteczność zaobserwowano w przypadku krajów rozwijających się w porównaniu do krajów rozwiniętych ${ }^{7}$. Zwykle wskaźniki charakteryzujące zmianę kondycji gospodarczej, takie jak stopa wzrostu PKB, są dodatnio powiązane z cenami akcji lub rynkowymi stopami zwrotu. Taką zależność potwierdzają przykładowo badania P. Amtirana i in., M. Hessa czy T. Singh, S. Mehta i M. Varshy ${ }^{8}$. Do odmiennych konkluzji prowadzi natomiast analiza J. Rittera. Zgodnie z nimi, w latach 1990-2002, pomiędzy stopami wzrostu dochodu per capita a stopami zwrotu z akcji zachodziła ujemna zależność. Badanie przeprowadzono na podstawie danych z 16 państw reprezentujących zdecydowaną większość (według autora wartość zbliżoną do 90\%) światowej kapitalizacji rynkowej, w związku z czym trudno zakładać obciążenie wyniku specyficznym doborem próby ${ }^{9}$. M. Celej, opierając się na danych dotyczących GPW, wskazała natomiast na brak istotnych zależności pomiędzy czynnikami makroekonomicznymi a kursami akcji ${ }^{10}$. Podobnie jak różnych wniosków dostarczyć mogą badania skupiające się na oszacowaniu wpływu zmiennych makroekonomicznych na ogólną kondycję giełdową, mierzoną stopami zwrotu i kursami akcji, niejednolita może być także siła oddziaływania wskaźników gospodarczych na liczbę IPO. Empiryczne badania w zakresie weryfikacji wpływu zmiennych makroekonomicznych na liczbę debiutów giełdowych opierają się zazwyczaj na danych takich jak stopy wzrostu PKB, stopy procentowe i stopy zwrotu z rynku giełdowego.

PKB jest miernikiem najczęściej wykorzystywanym w celu porównań sytuacji gospodarczej danego kraju na arenie międzynarodowej. Syntetycznie

kowe Uniwersytetu Ekonomicznego w Katowicach 2014/204; J. Ritter, Economic Growth and Equity Returns, Pacific Basin Finance Journal 2005/13; J. Barro, Economic Growth and Investment, National Bureau of Economic Research, Working Paper 2925, Cambridge 1989.

H. Wiśniewski, Wpływ zmiennych makroekonomicznych..., s. 98.

8 P. Amtiran, R. Indiastuti, R. Nidar, D. Masyita, Macroeconomic Factors and Stock Returns in APT Framework, International Journal of Economics and Management 2017/11 (1), s. 204-205; M. Hess, Sector Specific Impact of Macroeconomic Fundamentals on the Swiss Stock Market, Financial Markets and Portfolio Management 2003/17, s. 242; T. Singh, S. Mehta, M. Varsha, Macroeconomic Factors and Stock Returns: Evidence from Taiwan, Journal of Economics and International Finance 2011/2 (4), s. 225-226.

9 J. Ritter, Economic Growth and Equity Returns..., s. 490, 501.

10 M. Celej, Wpływ czynników makroekonomicznych na ceny akcji..., s. 44. 
ujmuje on wartość dodaną wytwarzaną w gospodarce w ciągu danego okre$\mathrm{su}^{11}$. Wówczas, gdy indeks ten rośnie, wnioskuje się o wzroście gospodarczym uznawanym za jeden z głównych celów funkcjonowania gospodarki. Wysokie tempo wzrostu PKB łączy się zazwyczaj z niską stopą bezrobocia, wówczas rośnie także skłonność do debiutów giełdowych ${ }^{12}$. Opierając się na tym stwierdzeniu, można by spodziewać się potencjalnie dodatniej zależności pomiędzy stopą wzrostu PKB a liczbą IPO. Empiryczna weryfikacja takiej konstatacji przeprowadzona przez I. Aidrous i S. Glavinę dostarczyła jednak odmiennych wyników, na podstawie których wysnuto wniosek o istnieniu istotnego statystycznie, ujemnego powiązania pomiędzy analizowanymi zmiennymi. Warto mieć jednak na uwadze fakt, że badanie to przeprowadzono na przykładzie państw arabskich cechujących się znaczącymi różnicami w rozwoju rynku giełdowego w stosunku do głównych państw europejskich ${ }^{13}$. Nieco inny rezultat uzyskany został przez L. Breinlinger i E. Glogovą. Ich analiza wskazała na brak znaczącej korelacji między stopą wzrostu PKB a liczbą debiutów giełdowych, tym razem opierając się o sytuację rynku europejskiego ${ }^{14}$. Pozytywną zależność pomiędzy analizowanymi zmiennymi potwierdzily natomiast prace autorstwa R. La Porty i in. oraz F. Langleta i F. Lilliehööka, przeprowadzone w oparciu o 15 państw Europy ${ }^{15}$. W kontekście polskiego rynku giełdowego warto wspomnieć o analizie T. Meluzina, M. Zineckera i J. Łapińskiej. Autorzy ci także wskazali na istnienie domniemanej wcześniej zależności, podobnie jak T. Meluzin i M. Zinecker we wcześniejszym badaniu ${ }^{16}$. Analogicznie, T. Dudycz zwrócił uwagę na istotną korelację pomiędzy stopą wzrostu PKB a liczbą debiutów giełdowych na

11 P. Samuelson, W. Nordhaus, Ekonomia, tom 1, Państwowe Wydawnictwo Naukowe, Warszawa 1996, s. 170-172.

12 E. Ostrowska, M. Deryło, Determinanty rozwoju rynku emisji..., s. 103.

13 I. Aidrous, S. Glavina, Impact of the Macroeconomic Factors..., s. 2320-2321.

14 L. Breinlinger, E. Glogova, Determinants of Initial Public Offerings: A European Time-Series Cross-Section Analysis, Financial Stability Report 3 Oesterreichische Nationalbank (Austrian Central Bank) 3, s. 99-100.

15 R. La Porta, F. Lopez-de-Silanes, A. Shleifer, R.W. Vishny, Legal Determinants of External Finance, National Bureau of Economic Research Working Paper 5879, Cambridge 1997, s. 14, 28; F. Langlet, F. Lilliehöök, The Impact of Macroeconomic Variables on IPO volume in Europe, praca magisterska, Królewski Instytut Technologiczny w Sztokholmie, Sztokholm 2017, s. 44.

16 T. Meluzin, M. Zinecker, J. Lapińska, Determinants of Initial Public Offerings: The Case of Poland, Revista de Métodos Cuantitativos Para la Economía y la Empresa, 2014/8, s. 15; T. Meluzin, M. Zinecker, Macro- and Microeconomics Aspects of Going Public in the Czech Republic and Poland, Procedia - Social and Behavioral Sciences 2014/156, s. 561-562. 
przykładzie GPW ${ }^{17}$. Biorąc powyższe pod uwagę, można sformułować hipotezę postaci:

(H1): Stopa wzrostu PKB wykazuje istotny, pozytywny wpływ na liczbę debiutów giełdowych przeprowadzanych na GPW.

Kolejną ze zmiennych, której wpływ na liczbę IPO był przedmiotem badań empirycznych, jest stopa procentowa wyrażająca punkt odniesienia dla kosztu kapitału. Teoretycznie wysoki poziom stopy procentowej wskazywać może na mniejsze możliwości przyszłego wzrostu dla przedsiębiorstw debiutujących na giełdzie. $\mathrm{Z}$ drugiej strony, porównanie prawdopodobieństwa decyzji o IPO i potencjalnym przejęciu innej spółki notowanej publicznie, przy wyższych stopach procentowych, wypada na korzyść debiutów giełdowych ${ }^{18}$. Z tej perspektywy nie jest jasne, jakiej zależności można spodziewać się pomiędzy stopą procentową a liczbą przeprowadzanych pierwszych ofert publicznych. Pewnego wglądu $\mathrm{w}$ tę kwestię dostarczają jednak wyniki badań empirycznych. L. Breinlinger i E. Glogova zanotowali brak znaczącej korelacji pomiędzy analizowanymi zmiennymi ${ }^{19}$. Na istnienie istotnej statystycznie zależności wskazały natomiast badania przeprowadzane w oparciu o sytuację na rynkach wschodzących - analizy autorstwa R. Ameera czy M. Uribe i V. Yue ${ }^{20}$. Empiryczne potwierdzenie ujemnego powiązania stóp procentowych z liczbą IPO dostarczyły także opracowania B. Jovanovica i P. Rousseau oraz E. Angelini i M. Foglii bazujące na obserwacjach krajów rozwiniętych ${ }^{21}$. Wobec tego postać hipotezy dotyczącej zależności pomiędzy stopami procentowymi a liczbą IPO jest następująca:

(H2): Stopa procentowa wykazuje istotny, ujemny wpływ na liczbę debiutów giełdowych przeprowadzanych na GPW.

T. Dudycz, Działalność inwestycyjna spótek debiutujacych na Giełdzie..., s. 13.

18 J. Brau, B. Francis, N. Kohers, The Choice of IPO versus Takeover: Empirical Evidence, Journal of Business 2003/76 (4), s. 594.

19 L. Breinlinger, E. Glogova, Determinants of Initial Public Offerings..., s. 99-100.

20 R. Ameer, Macroeconomic Factors and IPOs in Malaysia..., s. 45, 53; M. Uribe, V. Yue, Country Spreads and Emerging Countries: Who Drives Whom?, Journal of International Economics 2006/69, s. 33-34.

21 B. Jovanovic, P. Rousseau, Interest Rates and Initial Public Offerings, National Bureau of Economic Research Working Paper 10298, Cambridge 2004, s. 19; E. Angelini, M. Foglia, The Relationship Between IPO and Macroeconomic Factors: An Empirical Analysis from UK Market, Annals of Economics and Finance 2018/19 (1), s. 323, 334. 
Za wskaźnik makroekonomiczny mający istotny wpływ na liczbę debiutów giełdowych przyjąć można także stopę zwrotu z indeksu giełdowego. Zmienna ta wydaje się mieć pozytywny wpływ na liczbę IPO między innymi z uwagi na czynniki behawioralne. Wówczas gdy rynek osiąga zadowalające zwroty, przedsiębiorstwa potencjalnie zainteresowane debiutem giełdowym utwierdzają się w przekonaniu o jego słuszności ${ }^{22}$. Empiryczne potwierdzenie pozytywnego powiązania rynkowych stóp zwrotu z liczbą debiutów giełdowych dostarczyły m.in. badania R. Ameera, M. Pagano, F. Panetty i L. Zingalesa, T. Loughrana, J. Rittera i K. Rydqvista czy A. Tran i B. Jeon ${ }^{23}$. Nieco odmienne rezultaty otrzymali I. Aidrous i S. Glavina oraz E. Angelini i M. Foglia, których analizy wskazały na brak istotnych korelacji pomiędzy zmiennymi wziętymi pod uwagę ${ }^{24}$. Na przykładzie polskiego rynku pozytywną zależność pomiędzy zmiennymi wziętymi pod uwagę potwierdzili natomiast T. Meluzin, M. Zinecker i J. Łapińska $^{25}$. Uwzględniając rezultaty wyżej przywołanych badań, ostatnia z hipotez przedstawia się w ten sposób:

(H3): Stopa zwrotu z WIG (Warszawskiego Indeksu Giełdowego) wykazuje istotny, pozytywny wpływ na liczbę debiutów giełdowych przeprowadzanych na GPW.

Jak zasygnalizowano powyżej, badania skupiające się na określeniu wpływu wybranych zmiennych makroekonomicznych na liczbę IPO prowadzą często do zróżnicowanych wyników, głównie ze względu na różne rynki brane pod uwagę $\mathrm{w}$ analizach. Jednakże, na ich podstawie można było wstępnie określić hipotezy badawcze w odniesieniu do GPW. Wobec tego celowe wydaje się przeprowadzenie tego typu analizy konkretnie dla rynku polskiego, na bazie ostatnich kilkunastu lat.

22 T. Meluzin, M. Zinecker, J. Lapińska, Determinants of initial public offerings: The case of Poland, Revista de Metodos Cuantitativos para la Economia y la Empresa 2014/18 (1), s. 12.

23 R. Ameer, Macroeconomic Factors and IPOs in Malaysia..., s. 47, 53; M. Pagano, F. Panetta, L. Zingales, Why Do Companies Go Public? An Empirical Analysis, National Bureau of Economic Research Working Paper 5367, Cambridge 1995, s. 40; T. Loughran, J. Ritter, K. Rydqvist, Initial Public Offerings: International Insights, Pacific Basin Finance Journal 1994/2 (2), s. 181-182; A. Tran, B. Jeon, The Dynamic Impact of Macroeconomic Factors on Initial Public Offerings: Evidence from Time-Series Analysis, Applied Economics 2011/43 (23), s. 3192, 3198-3199.

24 I. Aidrous, S. Glavina, Impact of the Macroeconomic Factors..., s. 2321-2322; E. Angelini, M. Foglia, The Relationship Between IPO and Macroeconomic Factors..., s. 320, 323.

25 T. Meluzin, M. Zinecker, J. Lapińska, Determinants of initial public offerings..., s. 15. 


\section{Metodyka badania}

W ramach empirycznej weryfikacji wpływu zmiennych makroekonomicznych na liczbę IPO, skupiono się na analizie w dwóch ujęciach czasowych - kwartalnym i rocznym. W przypadku pierwszego $\mathrm{z}$ wymienionych pod uwagę wzięto dane dotyczące debiutów giełdowych z okresu III kwartał 2007 - II kwartał 2020, natomiast dla badania rocznego - z lat 2005-2019, co było podyktowane wyborem okresu bytności Polski w Unii Europejskiej (wiąże się to m.in. z większym dostępem do źródeł kapitału) oraz dostępnością danych. Dane dotyczące liczby debiutów pozyskano ze strony internetowej GPW (https://www.gpw.pl/), natomiast dotyczące zmiennych makroekonomicznych - ze strony internetowej Głównego Urzędu Statystycznego (https://stat.gov.pl/ - stopa wzrostu PKB), Narodowego Banku Polskiego (https://www.nbp.p1/ - stopa referencyjna) i serwisu Stooq (https://stooq.pl/ - rentowność obligacji skarbowych, stopy zwrotu z WIG).

Modele ekonometryczne konstruowane przez autorów badań wpływu zmiennych makroekonomicznych na liczbę IPO budowane były przykładowo w oparciu o klasyczną Metodę Najmniejszych Kwadratów (MNK), z wykorzystaniem regresji krokowej wstecznej ${ }^{26}$. W przypadku takich modeli odnotowywano zazwyczaj brak autokorelacji składnika losowego czy heteroskedastyczności reszt, a więc pożądane własności statystyczne. Wobec tego, także w ramach tego opracowania zdecydowano się skonstruować model regresji liniowej oparty na tej samej metodzie estymacji. Zmienną objaśnianą była liczba IPO (w przypadku której test ADF wskazał na stacjonarność z trendem liniowym), objaśniającymi zaś: stopa wzrostu PKB, stopa referencyjna NBP (jako oficjalna stopa procentowa) ${ }^{27}$, rentowność $10-$ letnich obligacji skarbowych (na rynku wtórnym) ${ }^{28}$ oraz stopa zwrotu z indeksu rynkowego (Warszawskiego Indeksu Giełdowego). Postać tego modelu przedstawia się następująco:

$$
\mathrm{nIPO}_{t}=\beta_{0}+\beta_{1} * \mathrm{dPKB}_{t-1}+\beta_{2} * \mathrm{rREF}_{t-1}+\beta_{3} * \mathrm{r} 10 \mathrm{~B}_{t-1}+\beta_{4} * \mathrm{rWIG}_{t-1}+\varepsilon_{t}
$$

26 Np. I. Aidrous, S. Glavina, Impact of the Macroeconomic Factors..., s. 2319; T. Meluzin, M. Zinecker, J. Lapińska, Determinants of initial public offerings..., s. 11.

27 Por. np. T. Meluzin, M. Zinecker, J. Lapińska, Determinants of initial public offerings..., s. 11; R. Ameer, Macroeconomic Factors and IPOs in Malaysia..., s. 43.

28 Por. np. L. Breinlinger, E. Glogova, Determinants of Initial Public Offerings..., s. 89; E. Angelini, M. Foglia, The Relationship Between IPO and Macroeconomic Factors..., s. 322. 
gdzie:

nIPO - liczba IPO,

dPKB - stopa wzrostu PKB [\%],

rREF - stopa referencyjna NBP na koniec okresu [\%],

r10B - rentowność 10-letnich obligacji skarbowych na koniec okresu [\%],

rWIG - stopa zwrotu z WIG [\%].

W ramach zmiennych objaśniających użyto wskaźników opóźnionych o 1 okres, co nawiązuje do metodyki badania T. Meluzina, M. Zinecker i J. Łapińskiej ${ }^{29}$. W związku z tym w ramach badania rocznego wykorzystano wskaźniki makroekonomiczne z okresu 2004-2018, zaś dane dotyczące liczby IPO - z lat 2005-2019.

\section{Analiza zależności między zmiennymi makroekonomicznymi a liczbą IPO}

Wstępnie obliczono współczynniki korelacji liniowej pomiędzy analizowanymi zmiennymi. Rezultat dla danych rocznych zobrazowano w tabeli 1.

TABELA 1: Macierz korelacji zmiennych w ujęciu rocznym

\begin{tabular}{|l|l|l|l|l|l|l|}
\hline & IPO_GPW & IPO_Sum & dPKB & rREF & r10B & rWIG \\
\hline IPO_GPW & 1,0000 & & & & & \\
\hline IPO_Sum & $0,9951^{* * *}$ & 1,0000 & & & & \\
\hline dPKB & 0,3315 & 0,365 & 1,0000 & & & \\
\hline rREF & $0,4926^{*}$ & $0,4766^{*}$ & 0,2242 & 1,0000 & & \\
\hline r10B & $0,5175^{* *}$ & $0,5322^{* *}$ & 0,2157 & $0,7755^{* * *}$ & 1,0000 & \\
\hline rWIG & $0,5394^{* *}$ & $0,5454^{* *}$ & $-0,1104$ & 0,0863 & 0,1940 & 1,0000 \\
\hline
\end{tabular}

Objaśnienia: *; **; *** oznacza, odpowiednio, istotność statystyczną na poziomie 0,10 ; 0,05; 0,01; IPO_GPW; IPO_Sum - odpowiednio: liczba IPO na Głównym Rynku GPW; łącznie $z$ debiutami na NewConnect.

Źródło: opracowanie własne.

Pomiędzy zmiennymi IPO_GPW i IPO_Sum zauważyć można zależność niemal funkcyjną, jednak nie jest to zaskakujące w kontekście stosunkowo niskiej liczby debiutów giełdowych na NewConnect w stosunku do sumy z GPW.

29 T. Meluzin, M. Zinecker, J. Lapińska, Determinants of initial public offerings..., s. 12. 
Liniowe powiązanie o znaczącej sile zaobserwować można także dla zmiennych rREF i r10B. Stopa referencyjna NBP i stopa rentowności 10-letnich obligacji skarbowych są istotnie współzależne, co także zgodne jest z intuicją - oficjalne stopy procentowe banku centralnego są punktem odniesienia dla rentowności skarbowych dłużnych papierów wartościowych. Mogłoby się wydawać, że przez pryzmat dość niskiej liczby obserwacji korelacja pomiędzy zmiennymi objaśniającymi o sile zbliżonej do 0,8 mogłaby zaburzać wnioski płynące $\mathrm{z}$ modelu, jednak test współliniowości nie potwierdził takiego przypuszczenia. Wobec tego, pod kątem statystycznym, powyższe zmienne mogą być wspólnie użyte $\mathrm{w}$ ramach budowy modeli regresji liniowej.

Analogicznie obliczono korelacje pomiędzy zmiennymi w ujęciu kwartalnym. Ich macierz przedstawiono w tabeli 2 .

TABELA 2: Macierz korelacji zmiennych w ujęciu kwartalnym

\begin{tabular}{|l|c|l|c|c|c|c|}
\cline { 2 - 7 } \multicolumn{1}{c|}{} & IPO_GPW & IPO_Sum & dPKB & rREF & r10B & rWIG \\
\hline IPO_GPW & 1,0000 & & & & & \\
\hline IPO_Sum & $0,9893^{* * *}$ & 1,0000 & & & & \\
\hline dPKB & $0,2951^{* *}$ & $0,3411^{* *}$ & 1,0000 & & & \\
\hline rREF & $0,4571^{* * *}$ & $0,4718^{* * *}$ & $-0,0004$ & 1,0000 & & \\
\hline r10B & $0,4353^{* * *}$ & $0,4522^{* * *}$ & 0,0757 & $0,8597 * * *$ & 1,0000 & \\
\hline rWIG & 0,1166 & 0,1049 & $-0,0946$ & $-0,1496$ & 0,0472 & 1,0000 \\
\hline
\end{tabular}

Objaśnienia: *; **; *** oznacza, odpowiednio, istotność statystyczną na poziomie 0,10 ; 0,05; 0,01; IPO GPW; IPO Sum - odpowiednio: liczba IPO na Głównym Rynku GPW; łącznie z debiutami na NewConnect.

Źródło: opracowanie własne.

Zmienne w ujęciu kwartalnym przejawiają powiązania liniowe o podobnej sile jak zmienne $\mathrm{W}$ ujęciu rocznym. W tym przypadku, przez pryzmat większej liczby obserwacji istotne statystycznie jest jednak także powiązanie pomiędzy dPKB a IPO_GPW i IPO_Sum, pomimo nieco niższej wartości współczynników korelacji. Współzależność rREF i r10B także zaobserwować można na wyższym poziomie niż w przypadku danych rocznych. Jednakże, również w tym przypadku rezultat testu współliniowości pozwolił na uwzględnienie wszystkich spośród powyższych zmiennych w modelu, poprawne pod kątem statystycznym.

Biorąc pod uwagę brak współliniowości pomiędzy zmiennymi objaśniającymi i ich korelację ze zmiennymi objaśnianymi, skupiono się na konstrukcji 
modeli. Z uwagi na bardzo wysoką współzależność pomiędzy IPO_GPW i IPO_Sum zdecydowano się skupić na drugiej ze zmiennych. Jako pierwszy przedstawiono wyjściowy model, bazujący na danych rocznych. Dalej zobrazowano modele $\mathrm{z}$ wyłączeniem parametrów, których oszacowania cechowały się najwyższą wartością p (w ramach regresji krokowej wstecznej). W tabelach 3-5 ukazano ich charakterystyki, w tabeli 6 zaś ich statystyczne własności.

TABELA 3: Model (1) oparty na danych rocznych

\begin{tabular}{|l|c|c|c|c|c|}
\cline { 2 - 6 } \multicolumn{1}{c|}{} & Współczynnik & Błąd stand. & t-Studenta & Wartość $\mathrm{p}$ & \\
\hline const & $-17,302$ & 15,9340 & $-1,0859$ & 0,30302 & \\
\hline dPKB & 401,348 & 245,8700 & 1,6324 & 0,13365 & \\
\hline rREF & 241,349 & 385,4550 & 0,6261 & 0,54525 & \\
\hline r10B & 302,597 & 471,9840 & 0,6411 & 0,53586 & \\
\hline rWIG & 39,7503 & 15,4492 & 2,5730 & 0,02775 & $* *$ \\
\hline
\end{tabular}

Źródło: opracowanie własne.

TABELA 4: Model (2) oparty na danych rocznych

\begin{tabular}{|l|c|c|c|c|c|}
\cline { 2 - 6 } \multicolumn{1}{c|}{} & Współczynnik & Błąd stand. & t-Studenta & Wartość p & \\
\hline const & $-19,7938$ & 14,9965 & $-1,3199$ & 0,21368 & \\
\hline dPKB & 413,2270 & 238,2670 & 1,7343 & 0,11076 & \\
\hline r10B & 528,0160 & 296,6660 & 1,7798 & 0,10271 & \\
\hline rWIG & 38,8757 & 14,9547 & 2,5996 & 0,02471 & $* *$ \\
\hline
\end{tabular}

Źródło: opracowanie własne.

TABELA 5: Model (3) oparty na danych rocznych

\begin{tabular}{|l|c|c|c|c|c|}
\cline { 2 - 6 } \multicolumn{1}{c|}{} & Współczynnik & Błąd stand. & t-Studenta & Wartość p & \\
\hline dPKB & 275,950 & 220,897 & 1,2492 & 0,23540 & \\
\hline r10B & 242,571 & 209,265 & 1,1592 & 0,26894 & \\
\hline rWIG & 38,8231 & 15,4101 & 2,5193 & 0,02694 & $* *$ \\
\hline
\end{tabular}

Źródło: opracowanie własne. 
TABELA 6: Własności modeli (1)-(3)

\begin{tabular}{|c|c|c|c|c|c|c|}
\hline Model & $\mathrm{R}^{2}$ & $\begin{array}{c}\text { Skorygowa- } \\
\text { ny } \mathrm{R}^{2}\end{array}$ & $\begin{array}{c}\text { Błąd stan- } \\
\text { dardowy } \\
\text { reszt }\end{array}$ & Test F & Test White'a & Test LM \\
\hline$(1)$ & 0,612 & 0,457 & 14,370 & $\begin{array}{c}\mathrm{F}(4,10)=3,9410 \\
(0,0357)\end{array}$ & $\begin{array}{c}\mathrm{LM}=10,0019 \\
(0,2649)\end{array}$ & $\begin{array}{c}\mathrm{LMF}=0,1686 \\
(0,6910)\end{array}$ \\
\hline$(2)$ & 0,597 & 0,487 & 13,967 & $\begin{array}{c}\mathrm{F}(3,11)=5,4244 \\
(0,0155)\end{array}$ & $\begin{array}{c}\mathrm{LM}=12,7936 \\
(0,1722)\end{array}$ & $\begin{array}{c}\mathrm{LMF}=0,0327 \\
(0,8601)\end{array}$ \\
\hline$(3)$ & 0,833 & 0,805 & 14,392 & $\begin{array}{c}\mathrm{F}(3,12)=19,8903 \\
(0,0001)\end{array}$ & $\begin{array}{c}\mathrm{LM}=12,9648 \\
(0,1131)\end{array}$ & $\begin{array}{c}\mathrm{LMF}=0,2685 \\
(0,6146)\end{array}$ \\
\hline
\end{tabular}

Źródło: opracowanie własne.

Biorąc pod uwagę rezultat estymacji modeli opartych na danych rocznych, można stwierdzić, że jedynie stopa zwrotu z WIG wykazywała istotne, pozytywne powiązanie z liczbą IPO przeprowadzanych na GPW w analizowanym okresie. W przypadku pozostałych zmiennych także zaobserwowano ich dodatni wpływ na liczbę debiutów giełdowych, oddziaływania te jednak nie były istotne statystycznie. W przypadku modeli (1)-(3) zaobserwować można było jednak łączną istotność oszacowań parametrów, brak autokorelacji i heteroskedastyczności reszt, a więc własności statystyczne, które można uznać za pożądane. Model (3) cechował się też dość wysokim stopniem objaśniania zmienności liczby pierwszych ofert publicznych, na poziomie przekraczającym $80 \%$. Znaki zgodne z oczekiwaniami zaobserwowano dla zmiennych dGDP i rWIG, natomiast odmienne - dla stóp procentowych. Na podstawie modeli (1)-(3) można stwierdzić, że stopa wzrostu PKB, referencyjna stopa procentowa NBP, rentowność 10-letnich obligacji skarbowych oraz stopa zwrotu z WIG były łącznie dodatnio powiązane z liczbą debiutów giełdowych w kolejnym roku. W kontekście zbudowanych modeli warto jednak wspomnieć o ograniczonej liczbie obserwacji, co mogło wpłynąć na brak istotności poszczególnych oszacowań parametrów. Wobec tego wydaje się, że bardziej wiarygodnych informacji mogą dostarczyć modele opracowane na podstawie danych kwartalnych, w ramach których uwzględniono kilkakrotnie więcej obserwacji. Rezultat ich estymacji zaprezentowano w tabelach 7-8, zaś ich statystyczne własności - w tabeli 9. 
TABELA 7: Model (4) oparty na danych kwartalnych

\begin{tabular}{|l|c|c|c|c|c|}
\cline { 2 - 6 } \multicolumn{1}{c|}{} & Współczynnik & Błąd stand. & t-Studenta & Wartość $\mathrm{p}$ & \\
\hline const & $-4,60427$ & 2,48676 & $-1,8515$ & 0,07038 & $*$ \\
\hline dPKB & 130,38200 & 41,3314 & 3,1545 & 0,00280 & $* * *$ \\
\hline rREF & 221,46300 & 93,7704 & 2,3618 & 0,02238 & $* *$ \\
\hline r10B & $-32,64160$ & 93,8603 & $-0,3478$ & 0,72957 & \\
\hline rWIG & 12,08450 & 6,55282 & 1,8442 & 0,07147 & $*$ \\
\hline
\end{tabular}

Źródło: opracowanie własne.

TABELA 8: Model (5) oparty na danych kwartalnych

\begin{tabular}{|l|c|c|c|c|c|}
\cline { 2 - 6 } \multicolumn{1}{c|}{} & Współczynnik & Błąd stand. & t-Studenta & Wartość $\mathrm{p}$ & \\
\hline const & $-5,02034$ & 2,10842 & $-2,3811$ & 0,02128 & $* *$ \\
\hline dPKB & 126,58600 & 40,57440 & 3,1199 & 0,00306 & $* * *$ \\
\hline rREF & 192,56400 & 44,38180 & 4,3388 & 0,00007 & $* * *$ \\
\hline rWIG & 11,226700 & 6,04915 & 1,8559 & 0,06961 & $*$ \\
\hline
\end{tabular}

Źródło: opracowanie własne.

TABELA 9: Własności modelu (4) i (5) ${ }^{30}$

\begin{tabular}{|c|c|c|c|c|c|}
\hline $\mathrm{R}^{2}$ & $\begin{array}{c}\text { Skorygowany } \\
\mathrm{R}^{2}\end{array}$ & $\begin{array}{c}\text { Błąd standardo- } \\
\text { wy reszt }\end{array}$ & Test $\mathrm{F}$ & Test White'a & Test LM \\
\hline 0,385 & 0,333 & 4,591 & $\begin{array}{c}\mathrm{F}(4,47)=7,3627 \\
(0,0001)\end{array}$ & $\begin{array}{c}\mathrm{LM}=23,2005 \\
(0,0571)\end{array}$ & $\begin{array}{c}\mathrm{LMF}=1,8845 \\
(0,1305)\end{array}$ \\
\hline 0,384 & 0,345 & 4,548 & $\begin{array}{c}\mathrm{F}(3,48)=9,7448 \\
(0,0000)\end{array}$ & - & - \\
\hline
\end{tabular}

Źródło: opracowanie własne.

Zwracając uwagę na oszacowania parametrów, istotne statystycznie było oddziaływanie stopy wzrostu PKB, referencyjnej stopy procentowej NBP oraz stopy zwrotu z indeksu giełdowego na liczbę IPO (w każdym przypadku dodatnie). Znaki tych oszacowań zgodne są z otrzymanymi dla modeli rocznych. Jednakże ujemne powiązanie zaobserwować można było między zmiennymi r10B

30 Model (5) estymowany był metodą Praisa-Winstena (UMNK) z uwagi na występowanie heteroskedastyczności reszt w modelu szacowanym MNK. Wobec tego niecelowe byłoby przeprowadzenie testów statystycznych pod kątem heteroskedastyczności i autokorelacji reszt. 
a IPO Sum, jednak była to nieistotna statystycznie współzależność. Oszacowania parametrów modeli okazały się być łącznie istotne statystycznie. Poza tym nie wykazano autokorelacji reszt ani heteroskedastyczności składnika losowego. Ponadto, błędy standardowe były znacznie niższe niż w przypadku modeli rocznych. Z drugiej jednak strony niższy był także stopień objaśniania zmienności liczby IPO na GPW przez modele (4) i (5). Skupiając się na wpływie poszczególnych zmiennych na liczbę debiutów giełdowych, zgodne z oczekiwaniami ich znaki przejawiała stopa wzrostu PKB oraz stopa zwrotu z indeksu giełdowego. Wzrost ich wartości w analizowanym okresie oddziaływał na liczbę IPO w kolejnym kwartale, co zgadza się z postawionymi hipotezami 1 i 3. Odmienne od oczekiwanego było natomiast powiązanie liczby debiutów giełdowych ze stopą referencyjną. Stopa ta również przejawiała dodatnią współzależność z liczbą pierwotnych ofert publicznych przeprowadzanych na GPW.

Biorąc pod uwagę modele oparte na danych kwartalnych, wskazano na istotność statystyczną oszacowań większej liczby parametrów niż w przypadku modeli rocznych. Istotnie powiązane ze zmienną objaśnianą okazały się być stopa wzrostu PKB, referencyjna stopa procentowa NBP i stopa zwrotu z indeksu giełdowego. Jednakże modele (4) i (5) cechowały się niższymi wartościami współczynnika $\mathrm{R}^{2}$, ale też i niższym błędem standardowym reszt w porównaniu do modeli (1)-(3).

\section{Zakończenie}

Sumarycznie, skupiając się zarówno na modelach (1)-(3), jak i (4)-(5), wskazać można na istotne powiązanie stopy zwrotu z WIG z liczbą debiutów giełdowych przeprowadzanych na GPW. W przypadku modeli kwartalnych znaczącą współzależność z liczbą IPO w kolejnym roku przejawiały także stopa referencyjna NBP oraz stopa wzrostu PKB. Oszacowania wszystkich spośród tych zmiennych były dodatnie. Wobec tego za potwierdzoną uznać można hipotezę 3 , a także częściowo 1, traktujące odpowiednio o pozytywnym powiązaniu stopy zwrotu z WIG oraz stopy wzrostu PKB z liczbą IPO w kolejnym okresie ${ }^{31}$. Hipoteza 2, w świetle niniejszego opracowania, nie znajduje natomiast potwierdzenia.

31 Wynik ten, w odniesieniu do stopy wzrostu PKB, jest zgodny z rezultatem otrzymanym przez F. Langleta i F. Lilliehöök oraz T. Meluzina, M. Zineckera i J. Lapińską, jest natomiast odmienny niż rezultat badania I. Aidrous i S. Glaviny. Rezultat odnoszący się do stopy zwrotu z indeksu giełdowego zgodny jest zaś z wynikami badań M. Pagano, F. Panetty i L. Zingalesa oraz T. Meluzina, M. Zineckera i J. Łapińskiej. 
Stopy procentowe nie wpływały negatywnie na liczbę debiutów giełdowych w analizowanym okresie. W przypadku stopy referencyjnej NBP zaobserwowano dodatnie oddziaływanie na liczbę IPO, podobnie jak w przypadku rentowności 10-letnich obligacji skarbowych (w modelach rocznych, jednak była to statystycznie nieistotna zależność ${ }^{32}$. Otrzymane rezultaty wskazują na celowość przeprowadzania badań wpływu zmiennych makroekonomicznych na zmienne związane z rynkiem giełdowym, takie jak liczba IPO. Przez pryzmat dynamicznych zmian w sferze gospodarczej warto weryfikować, czy oddziaływanie takich wskaźników uległo zmianie na przestrzeni lat, a także, czy jest tożsame dla różnych rynków. Na podstawie niniejszego badania można stwierdzić, że niekoniecznie - otrzymane rezultaty były zgodne z niektórymi wynikami poprzednich badań, różniąc się natomiast od innych. Opierając się na otrzymanych rezultatach, biorąc pod uwagę GPW, w analizowanym okresie wzrost dynamiki PKB i stopy zwrotu $\mathrm{z}$ indeksu giełdowego, a także referencyjnej stopy procentowej znajdował odzwierciedlenie w większej liczbie debiutujących podmiotów w kolejnym okresie.

W kontekście zaprezentowanej analizy porównać można także modele zbudowane na podstawie danych rocznych i kwartalnych. W przypadku pierwszej z tych grup zaobserwować można było wyższy stopień dopasowania modeli do danych. Modele oparte na danych kwartalnych cechowały się natomiast statystyczną istotnością większej liczby parametrów. W świetle tych wyników wydaje się, że warto modelować zależności pomiędzy zmiennymi makroekonomicznymi a liczbą IPO zarówno w ujęciu rocznym, jak i kwartalnym, opóźniając też zmienną objaśnianą o 1 okres. Zazwyczaj badania tego typu przeprowadzane były na bazie danych rocznych, a więc powyższy wniosek może być użyteczny pod kątem przyszłych analiz w tym zakresie. Celowe wydaje się także uwzględnienie większej liczby zmiennych oddziałujących na liczbę IPO w ujęciu kwartalnym, co powinno pozwolić na objaśnianie zmienności tej liczby w większym stopniu oraz wydłużenie okresu analizy w przypadku modeli rocznych. Należy mieć też świadomość, że zmianie ulegają prawne definicje odnoszące się do pierwszej oferty publicznej, co może wpływać na rezultaty tego typu badań.

32 Rezultat ten, w odniesieniu do stopy referencyjnej, jest odmienny od rezultatów badań R. Ameera, odnosząc się zaś do rentowności obligacji skarbowych - otrzymany wynik różni się od rezultatu badania E. Angelini i M. Foglii. 


\section{Bibliografia}

\section{Opracowania}

Aidrous I., Glavina S., Impact of the Macroeconomic Factors on the Initial Public Offerings in the Gulf Cooperation Countries, Advances in Economics, Business and Management Research 2020/128, s. 2316-2325.

Ameer R., Macroeconomic Factors and IPOs in Malaysia, Asian Academy of Management Journal of Accounting and Finance 2012/8 (1), s. 1-30.

Amtiran P.Y., Indiastuti R., Nidar S.R., Masyita D., Macroeconomic Factors and Stock Returns in APT Framework, International Journal of Economics and Management 2017/11 (1), s. $197-206$.

Angelini E., Foglia M., The Relationship Between IPO and Macroeconomic Factors: An Empirical Analysis from UK Market, Annals of Economics and Finance 2018/19 (1), s. 319-336.

Barro J., Economic Growth and Investment, National Bureau of Economic Research, Working Paper 2925, Cambridge 1989.

Brau J.C., Francis B., Kohers N., The Choice of IPO versus Takeover: Empirical Evidence, Journal of Business 2003/76 (4), s. 583-612.

Breinlinger L., Glogova E., Determinants of Initial Public Offerings: A European Time-Series Cross-Section Analysis, Financial Stability Report 3 Oesterreichische Nationalbank (Austrian Central Bank) 3, s. 87-106.

Celej M., Wpływ czynników makroekonomicznych na ceny akcji na polskim rynku giełdowym, Studia Ekonomiczne. Zeszyty Naukowe Uniwersytetu Ekonomicznego w Katowicach 2014/204, s. 30-46.

Dudycz T., Działalność inwestycyjna spółek debiutujących na Giełdzie Papierów Wartościowych w Warszawie, Oficyna Wydawnicza Politechniki Wrocławskiej, Wrocław 2013.

Hess M., Sector Specific Impact of Macroeconomic Fundamentals on the Swiss Stock Market, Financial Markets and Portfolio Management 2003/17, s. 234-245.

Jovanovic B., Rousseau P.L., Interest Rates and Initial Public Offerings, National Bureau of Economic Research, Working Paper 10298, Cambridge 2004.

La Porta R., Lopez-de-Silanes F., Shleifer A., Vishny R.W., Legal Determinants of External Finance, National Bureau of Economic Research Working Paper 5879, Cambridge 1997.

Langlet F., Lilliehöök F., The Impact of Macroeconomic Variables on IPO volume in Europe, praca magisterska, Królewski Instytut Technologiczny w Sztokholmie, Sztokholm 2017.

Loughran T., Ritter J., Rydqvist K., Initial Public Offerings: International Insights, Pacific Basin Finance Journal 1994/2 (2), s. 165-200.

Meluzin T., Zinecker M., Macro- and Microeconomics Aspects of Going Public in the Czech Republic and Poland, Procedia - Social and Behavioral Sciences 2014/156, s. 558-563.

Meluzin T., Zinecker M., Lapińska J., Determinants of Initial Public Offerings: The Case of Poland, Revista de Metodos Cuantitativos para la Economia y la Empresa 2014/18 (1), s. $5-17$.

Okoń Sz., Gemra K., Zmiany regulacyjne a rynek pierwszych ofert publicznych (IPO) w Polsce, Kwartalnik Nauk o Przedsiębiorstwie 2020/54 (1), s. 81-90.

Ostrowska E., Deryło, M., Determinanty rozwoju rynku emisji pierwotnych akcji na Giełdzie Papierów Wartościowych w Warszawie, Zeszyty Naukowe Uniwersytetu Ekonomicznego w Krakowie 2015/937 (1), s. 101-114. 
Pagano M., Panetta F., Zingales L., Why Do Companies Go Public? An Empirical Analysis, National Bureau of Economic Research Working Paper 5367, Cambridge 1995.

Ritter J., Economic Growth and Equity Returns, Pacific Basin Finance Journal 2005/13, s. 489-503.

Samuelson P., Nordhaus W., Ekonomia, tom 1, Państwowe Wydawnictwo Naukowe, Warszawa 1996.

Singh T., Mehta S., Varsha M., Macroeconomic Factors and Stock Returns: Evidence from Taiwan, Journal of Economics and International Finance 2011/2 (4), s. 217-227.

Tran A.L., Jeon B.N., The Dynamic Impact of Macroeconomic Factors on Initial Public Offerings: Evidence from Time-Series Analysis, Applied Economics 2011/43 (23), s. 3187-3201.

Uribe M., Yue V.Z., Country Spreads and Emerging Countries: Who drives whom?, Journal of International Economics 2006/69, s. 6-36.

Wiśniewski H., Wpływ zmiennych makroekonomicznych na indeksy giełdowe, praca doktorska, Uniwersytet Warszawski, Warszawa 2014.

\title{
Strony internetowe
}

https://emerging-europe.com/news/poland-promoted-to-developed-market-status-by-ftse-russell, stan na 4.12.2020 r.

https://stat.gov.pl/, stan na 4.12.2020 r.

https://stooq.pl/, stan na 4.12.2020 r.

https://www.gpw.pl/, stan na 4.12.2020 r.

https://www.nbp.pl/, stan na 4.12.2020 r.

Bartłomiej PILCH

\section{IMPACT OF MACROECONOMIC VARIABLES ON THE NUMBER OF FIRST PUBLIC OFFERS ON THE EXAMPLE OF THE WARSAW STOCK EXCHANGE}

\begin{abstract}
Background: The impact of macroeconomic variables on the number of initial public offerings (IPOs) was analysed. Individual general economic indicators affect the stock market in different ways. The results of research taking into account their impact on the number of IPOs carried out in different countries are also varied. Therefore, it was decided to conduct an analysis in this respect, focusing on the Warsaw Stock Exchange (WSE), indirectly trying to check whether the results of foreign research are reflected in the situation of the Polish market.

Research purpose: The main motive for undertaking the research was to verify the impact of selected macroeconomic indicators on the number of IPOs. This goal was followed by the following research hypotheses: the GDP growth rate positively influences the number of IPOs, the interest rate negatively affects this variable, and the increase in the rates of return on the Warsaw Stock Exchange Index (WIG) contributes to the increase in the number of IPOs.

Methods: Empirical verification of macroeconomic variables' impact on the number of IPOs was carried out using linear regression models. For the annual models, the estimation was carried out using the Least Squares (OLS) method, and in the case of quarterly models - also using the Generalized Least Squares (GLS) method in order to avoid heteroscedasticity of the residuals. The number of IPOs in 2005-2019 was analysed and explained with indicators delayed by 1 period.
\end{abstract}


Conclusions: The rate of return on WIG had a significant positive impact on the number of IPOs in the next period, both under annual and quarterly models. In the case of other variables, their significant impact on the number of IPOs was observed only in the case of quarterly ones. The GDP growth rate showed a positive correlation with the number of IPOs, which is in line with the previously formulated hypothesis, similarly to the rates of return from WIG. A positive impact on the number of IPOs was also noted in the case of the reference interest rate - this result differed from the expected one. Apart from the results of the study, one can also point to the purposefulness of using models prepared on the basis of both annual and quarterly data, in the case of examining the impact of macroeconomic variables on the number of IPOs.

Keywords: IPO, GDP growth rate, interest rate, return on the stock exchange index, WSE. 